\title{
Rockefeller head quits as scandal looms
}

\section{Erika Check, Washington}

Arnold Levine has resigned as president of Rockefeller University in New York amid reports of a public and allegedly inappropriate encounter with a female graduate student.

In a statement issued on 10 February, 62 -year-old Levine said he was leaving to address matters affecting his health. "In light of my health issues, I regret I will not be able to continue to lead this extraordinary institution and these talented people," he wrote.

But sources at the university confirmed reports that Levine has resigned over what one of them described as an "inappropriate incident" with a female graduate student that occurred on 10 January. Various reports of the encounter have swept through Rockefeller in recent weeks.

According to the sources, the encounter occurred in the university's faculty club, a popular meeting place for researchers and graduate students. Both Levine and the participating student were intoxicated, the sources say, and she is said to have told university officials that the encounter was consensual. A male student who was in the faculty club confronted Levine during the encounter, one of the sources says, at which point Levine became angry. This student reported the incident to the Board of Trustees.

Levine, who was the first to isolate the $\mathrm{p} 53$ tumour-suppressor protein, rushed back on 8 February from a meeting held to mark the opening of the Spanish National Cancer
Centre in Madrid. Summoned by the Board of Trustees, he expressed profound regrets and said he would resign, says a source familiar with the situation. Levine was unavailable to comment on the incident.

Thomas Sakmar, who works on mechanisms of cell signalling and has headed the university's Academic Senate for the past year, has since been appointed acting president while the board sets about selecting a permanent replacement for Levine.

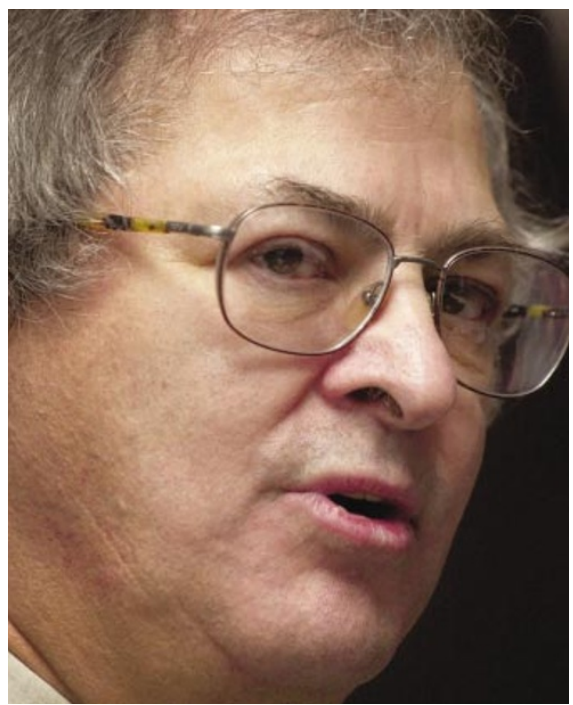

Arnold Levine resigned as president soon after a meeting with Rockefeller's trustees.
In a statement, Richard Fisher, chairman of Rockefeller's Board of Trustees, called Levine an "admired and inspirational leader" and said Levine had "helped strengthen the university and position it for continued preeminence as it enters its second century".

The resignation has shocked and saddened many inside and outside Rockefeller's campus on Manhattan's upper east side.

Harold Varmus, former director of the National Institutes of Health and current president of the Memorial Sloan-Kettering Cancer Center in New York, says that Levine had been instrumental in strengthening the research community in New York. "There will be an empty ache not having Arnie at the helm across the street,"Varmus says.

Levine left Princeton University in 1998 to lead Rockefeller. He is widely credited with reinvigorating the small but prestigious university, which had suffered a blow to its morale with the forced resignation of David Baltimore as president in 1991. Baltimore left amid charges that a co-author had falsified data in a 1986 paper - a charge that was dismissed by a federal appeals panel in 1996. $\mathrm{He}$ is now president of the California Institute of Technology in Pasadena.

Baltimore says that Levine was successful at Rockefeller, recruiting good people and raising money effectively. "I think Arnie's been doing a terrific job," Baltimore says. "Rockefeller is the kind of institute he understands, and he'll be a very hard person to replace."

\section{Soros offers open access to science papers}

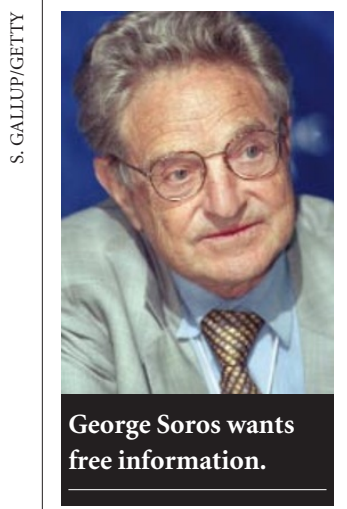

Declan Butler George Soros, the Hungarian-born financier and philanthropist, is backing a new effort to provide free and unrestricted access to scientific and other academic literature.

Soros's Open Society Institute (OSI) will launch the new initiative in Budapest on 14 February, pledging US\$3 million in grants over three years to support free electronic article repositories and 'alternative' journals committed to open access.

Peter Suber, a philosopher at Earlham College in Richmond, Indiana, and one of the architects of the 'Budapest Open Archive Initiative', says that this sum will go a long way. He notes that electronic repositories are not expensive to set up, and that the opensource software required to run such repositories is already freely available on the Internet.

But Suber and others involved in the initiative concede that further funding will ultimately be required, and that their broader aim is to create a "domino effect" by convincing other funders and research institutions to become involved.

The initiative is publicly supported by around $\mathbf{3 0 0}$ individuals, including the provosts of the California Institute of Technology and the University of Kansas. The 20 organizations listed as supporters include the Public Library of Science, the University of Illinois at Urbana-Champaign and the University of Missouri-Columbia.

The initiative shares some of its objectives with the Public Library of Science, which last year sought to organize a researchers' boycott of journals that refused to cooperate with its campaign for free access to scientific literature. But instead of seeking to influence publishers, the Budapest initiative will attempt to win support for open-access publishing from within the academic community.

Research institutions and funding agencies that sign up commit themselves to making policy changes, such as creating local open-access electronic repositories, and making it compulsory for grant recipients to deposit their papers there. Individual signatories agree to deposit their research in freely available electronic repositories, and to support alternative journals as authors, editors and referees.

"Only time will tell if the impact of the OSI will be large or small," says Suber. "We only need enough money to change the business model of enough scholarly resources to give momentum to this better way. The money already in the system is more than enough to pay for open access," he adds.

www.osi.hu 